\title{
Analisis Kepuasan Pasien Dilihat dari Minat untuk Dirawat Kembali Terhadap Pelayanan Dokter dan Perawat
}

\author{
Lailil Masruron*, Tjahjono Kuntjoro**, Martha Irene Kartasurya ** \\ *Alumni Magister Ilmu Kesehatan Masyarakat Universitas Diponegoro, \\ **Staf Pengajar Program Magister Ilmu Kesehatan Masyarakat Universitas Diponegoro \\ Email : laililmasruron85@gmail.com
}

\section{ABSTRACT}

Bed Occupancy Rate (BOR) at Dolopo Public Hospital had decreased from $56.16 \%$ in 2013 to $35.86 \%$ in 2104 and $35.2 \%$ in 2015, and the average ALOS (Average Length of Stay) and Turn over Interval (TOI) increased. The preliminary study on patients of Social Security Agency (BPJS Non PBI) showed a dissatisfaction to nurse's and doctor's services. The aim of this study was to analyze the associations between patient satisfaction toward doctor's \& nurse's services to the interest to be rehospitalized. This study was conducted in a cross sectional design. The subjects were 95 patients of BPJS with Non PBI in inpatient room for class I, II, III, which was choosen by using accidental sampling. Data were gathered through interviews using structured questionnaires. Data analysis was conducted by Chi-square tests and logistic regression.

Results showed that the patient satisfaction based on aspects of tangibles, reliability, responsiveness, assurance, and empathy were lower than the expectations. Most of the subjects have positive attitudes, negative subjective norms and perceptions of behavior control and had a poor accesibility to the hospital. However 75.8\% of the respondents were interested to be rehospitalized at Dolopo Hospital. There were correlations between patient satisfaction $(p=0.009)$, attitude $(p=0.000)$, subjective norm $(p=0.002)$ with the interest to be rehospitalized. There was no correlation between control perception behavior $(p=0.103)$, and access $(p=0.454)$ with the interest to be rehospitalized. After controlled for the attitude toward doctors' and nurses' services, the patients who were satisfied to the doctor' and nurses' services had 3.84 times to be interested to be rehospitalized than the patients who were not satifsfied $(O R=3.84 ; C I 95 \%: 0.98$ 15.12, $p=0.054)$.

Keywords : Patient Satisfaction, Rehospitalized, BPJS.

\section{PENDAHULUAN}

Rumah Sakit merupakan salah satu bagian dari sistem pelayanan kesehatan yang memberikan pelayanan untuk masyarakat yang mencakup pelayanan medik, pelayanan penunjang medik, rehabilitasi medik dan pelayanan perawatan Undang-Undang Republik Indonesia No. 44 tahun 2009 tentang Rumah Sakit, menyebutkan bahwa "Rumah Sakit adalah institusi pelayanan kesehatan yang menyelenggarakan pelayanan kesehatan perorangan secara paripurna yang menyediakan pelayanan rawat inap, rawat jalan, dan gawat darurat" $" 1,2$.

Saat ini Rumah Sakit Umum Daerah Dolopo mengalami penurunan BOR setiap tahunnya yaitu tahun 2013 sebanyak 56,2\%, tahun 2014 sebanyak 35,86\%, tahun 2015 
sebanyak 35,2\%, tahun 2016 sebanyak 40,5\%, dan tahun 2017 sebanyak 49,77\%. Dari penilaian BOR tersebut belum bisa mencapai target yang ditetapkan oleh Depkes RI setiap tahunnya yaitu dibawah standar rata-rata kurang dari $60-85 \%$, dan peningkatan terhadap rata-rata nilai ALOS (rata-rata lamanya pasien dirawat) pada tahun 2013 sebanyak 3,5 hari, tahun 2014 sebanyak 2,2 hari, tahun 2015 sebanyak 3,3 hari, tahun 2016 sebanyak 3,5 hari, dan tahun 2017 sebanyak 3,08 hari. Angka tersebut masih memenuhi standar yang ditetapkan oleh Depkes RI yaitu dibawah 69 hari. Akan tetapi pencapaian rata-rata lamanya pasien dirawat dari tahun ke tahun terus meningkat, sehingga akan menyebabkan terjadinya kualitas pelayanan kurang maksimal. Begitu juga nilai TOI (Turn Over Interval) setiap tahunnya mengalami peningkatan yaitu pada tahun 2013 sebanyak 2,2 hari, tahun 2014 sebanyak 5,7 hari, tahun 2015 sebanyak 6 hari, tahun 2016 sebanyak 5,2 hari, dan tahun 2017 sebanyak 3,13 hari. Pencapaian nilai tersebut tidak sesuai dengan nilai ideal yang telah di tetapkan oleh Depkes RI yaitu antara 1-3 hari ${ }^{3,4}$.

Rumah Sakit Umum Daerah Dolopo Kabupaten Madiun yang menggunakan fasilitas program BPJS pada bulan Maret Tahun 2015 terhadap 10 pasien BPJS Non PBI di ruang rawat inap diperoleh hasil bahwa untuk $80 \%$ (8 pasien) kurang puas terhadap pelayanan dokter dan $60 \% \quad(6$ pasien) kurang puas terhadap pelayanan perawat, $40 \%$ (4 pasien) menyatakan bahwa ketersediaan obat di apotek rumah sakit masih kurang, serta $20 \% \quad$ (2 pasien) menyatakan bahwa ruang rawat inap kurang bersih dan rapi, dan ruang rawat inap kurang nyaman, sehingga tujuan dari penelitian ini adalah untuk menganalisis kepuasan pasien terhadap pelayanan dokter dan perawat berhubungan dengan minat untuk dirawat kembali. Studi di RSUD Dolopo Kabupaten Madiun.

\section{METODE PENELITIAN}

Penelitian ini merupakan penelitian kuantitatif, analitik observasional dengan menggunakan pendekatan Cross Sectional. Penelitian ini dilaksanakan di RSUD Dolopo Kab. Madiun. Data primer diperoleh melalui wawancara langsung kepada responden dengan alat bantu kuesioner terstruktur. Populasi pada penelitian ini adalah seluruh pasien rawat inap BPJS ruang kelas I, II, dan III di tahun 2016. Subjek dalam penelitian ini pasien rawat inap BPJS Non PBI ruang kelas I, II, dan III tahun 2016 sebanyak 95 responden, yang dipilih secara aksidental sampling. Analisis data dilakukan dengan menggunakan uji Chi Square dan regresi logistic.

\section{HASIL DAN PEMBAHASAN}

Gambaran responden RSUD Dolopo Kab.Madiun ditujukan pada Tabel 1.

Tabel 1. Karakteristik responden.

\begin{tabular}{llcc}
\hline \multicolumn{1}{c}{ Karakteristik } & \multicolumn{1}{c}{ Kategori } & F & \% \\
\hline Umur & $>45$ (Lansia) & 61 & 64,2 \\
Jenis Kelamin & Perempuan & 57 & 60,0 \\
Pendidikan & SD & 54 & 56,8 \\
Pekerjaan & Ibu Rumah Tangga & 32 & 33,7 \\
& Petani & 30 & 31,6 \\
Pendapatan & < UMR (Dibawah & 80 & 84,2 \\
Kelas Perawatan & UMR) & 52 & 54,7 \\
\hline
\end{tabular}

Berdasarkan Tabel 1 diketahui sebagian besar responden berusia $>45$ tahun, yaitu sebanyak $(64,2 \%)$, berjenis kelamin perempuan $(60,0 \%)$, dengan tingkat pendidikan terakhir adalah SD $(56,8 \%)$, sebanyak $(33,7 \%)$ pekerjaanya adalah Ibu rumah tangga dan petani sebanyak (31,6\%), sebanyak $(84,2 \%)$ mempunyai penghasilan di bawah UMR dan sebanyak $(54.7 \%)$ responden berada di ruang kelas III.

Tabel 2. Kepuasan pasien dengan minat untuk dirawat kembali.

\begin{tabular}{llcc}
\hline Variabel Penelitian & Kategori & F & \% \\
\hline Kepuasan Pasien & & & \\
Aspek tangibles & Tidak Puas & 59 & 62,1 \\
Aspek reliability & Tidak Puas & 52 & 54,7 \\
Aspek responsiveness & Tidak Puas & 48 & 50,5 \\
Aspek assurance & Tidak Puas & 48 & 50,5 \\
Aspek empathy & Tidak Puas & 51 & 53,7 \\
\hline
\end{tabular}


Berdasarkan Tabel 2 diketahui sebagian besar responden tidak puas terhadap aspek tangibles (penampilan) pelayanan dokter dan perawat, yaitu sebanyak $(62,1 \%)$.

Tabel 3. Faktor-faktor determinan minat dirawat kembali.

\begin{tabular}{llcc}
\hline Variabel Penelitian & Kategori & F & \% \\
\hline Sikap & Positif & 65 & 68,4 \\
Norma Subjektif & Positif & 38 & 40,0
\end{tabular}

Persepsi Kontrol

Perilaku

Positif

Persepsi Pasien

Terhadap Tempat

Kurang Baik

81

85,3

(akses)

Berdasarkan Tabel 3 diketahui hasil analisis terhadap gambaran tentang minat untuk dirawat kembali menunjukkan bahwa dari 95 responden sebagian besar berminat untuk dirawat kembali $(75,8 \%)$.

Tabel 3. Rekapitulasi hasil analisis bivariat.

\begin{tabular}{|c|c|c|c|c|c|c|}
\hline \multirow{3}{*}{ Variabel } & \multirow{3}{*}{ Kategori } & \multicolumn{4}{|c|}{ Minat Untuk Dirawat Kembali } & \multirow[t]{3}{*}{ P -Value } \\
\hline & & \multicolumn{2}{|c|}{ Tidak Berminat } & \multicolumn{2}{|c|}{ Berminat } & \\
\hline & & $\mathbf{n}$ & $\%$ & $\mathbf{N}$ & $\%$ & \\
\hline \multirow{2}{*}{ Kepuasan Pasien } & Tidak Puas & 17 & 73,9 & 31 & 43,1 & \multirow{2}{*}{0,009} \\
\hline & Puas & 6 & 26,1 & 41 & 56,9 & \\
\hline \multirow{2}{*}{ Sikap } & Negatif & 20 & 87,0 & 10 & 13,9 & \multirow{2}{*}{0,000} \\
\hline & Positif & 3 & 13,0 & 62 & 86,1 & \\
\hline \multirow{2}{*}{ Norma Subjektif } & Negatif & 20 & 87,0 & 37 & 51,4 & \multirow{2}{*}{0,002} \\
\hline & Positif & 3 & 13,0 & 35 & 48,6 & \\
\hline \multirow{2}{*}{ Persepsi Kontrol Perilaku } & Negatif & 18 & 78,3 & 44 & 61,1 & \multirow{2}{*}{0,103} \\
\hline & Positif & 5 & 21,7 & 28 & 38,9 & \\
\hline \multirow{2}{*}{$\begin{array}{l}\text { Persepsi Terhadap Tempat } \\
\text { (akses) }\end{array}$} & Kurang Baik & 19 & 82,4 & 62 & 86,1 & \multirow{2}{*}{0,454} \\
\hline & Baik & 4 & 17,4 & 10 & 13,9 & \\
\hline
\end{tabular}

Tabel 4. Hasil analisis Multivariat dengan Regresi Logistik.

\begin{tabular}{lccccccccc}
\hline \multicolumn{1}{c}{ Variabel } & \multirow{2}{*}{ B } & \multirow{2}{*}{ S.E. } & \multirow{2}{*}{ Wald } & df & P & OR & \multicolumn{2}{c}{ IK95\% } \\
\cline { 7 - 10 } & & & & & & & Min & Maks \\
\hline Kepuasan Pasien (1) & 1,346 & 0,699 & 3,705 & 1 & 0,054 & 3,841 & 0,98 & 15,12 \\
Sikap (1) & 3,732 & 0,734 & 25,859 & 1 & 0,000 & 41,774 & 9,91 & 176,05 \\
\hline
\end{tabular}

\section{PEMBAHASAN}

Ada hubungan antara kepuasan pasien ditinjau dari aspek penampilan, keandalan, daya tanggap, jaminan, dan perhatian terhadap pelayanan dokter dan perawat dengan minat untuk dirawat kembali. Hubungan tersebut mempunyai korelasi yang positif artinya jika pasien selama mendapatkan pelayanan di rumah sakit lebih baik daripada yang diharapkan maka dia akan puas, sebaliknya jika pengalaman selama mendapatkan pelayanan di rumah sakit lebih rendah (lebih buruk) daripada yang mereka harapkan maka mereka akan merasa tidak puas ${ }^{5}$.

Hasil ini sesuai dengan penelitian yang dilakukan di PUSKESMAS Wisma
Jaya Kota Bekasi, yang membuktikan bahwa kepuasan pasien bayar terhadap mutu pelayanan kesehatan puskesmas wisma jaya mempunyai hubungan bermakna dengan minat kunjungan ulang pelayanan kesehatan ${ }^{6}$.

Kepuasan pasien dipengaruhi oleh faktor perilaku dan sikap dokter, perawat, dan petugas lainnya, maka komponen lainnya yang juga mempengaruhi kepuasan pasien adalah pelayanan administrasi masuk, dan administrasi selama pasien dirawat, keuangan, pelayan makan (bagi pasien rawat inap), pelayanan perawat yang jarang menjenguk keadaan pasien, pelayanan laboratorium dan penunjang diagnostik lainnya, kondisi ruang perawatan, serta kebersihan, kenyamanan, 
dan keamanan lingkungan rumah sakit ${ }^{5}$. Hal ini juga sesuai dengan penelitian di PUSKESMAS Ranotana Weru Kota Manado yang menyatakan ada hubungan antara kepuasan pasien terhadap kualitas jasa pelayanan rawat jalan dengan minat untuk memanfaatkan kembali pelayanan kesehatan ${ }^{7}$.

Kepuasan pasien dapat memberikan beberapa manfaat, diantaranya hubungan antara organisasi pemberi layanan, pelanggannya menjadi harmonis, memberikan dasar baik bagi pembeli ulang, terciptanya loyalitas pasien, dan membentuk suatu rekomendasi dari mulut ke mulut (word-of-mouth) yang menguntungkan bagi perusahaan (rumah sakit) ${ }^{8}$.

Ada hubungan antara sikap dengan minat untuk dirawat kembali, artinya semakin baik sikap seseorang maka akan semakin baik keyakinan seseorang untuk melakukan kunjungan ulang (minat untuk dirawat kembali).

Hasil penelitian ini sesuai dengan penelitian yang dilakukan di RS Adi Husada Undaan Wetan yang menyatakan bahwa sikap berhubungan secara positif terhadap minat menggunakan layanan medical check up. Makin positif sikap seseorang, makin positif keyakinan seseorang akan harapan kelompok sosial dan makin tinggi tingkat persepsi seseorang terhadap kontrol yang dimilikinya akan makin mendorong minat orang tersebut dalam menggunakan layananan. ${ }^{9}$

Menurut Ajzen sikap dianggap sebagai penyebab paling utama dari niat beperilaku. Sikap ini sering diperoleh dari pengalaman individu atau orang lain yang paling dekat. Sikap membuat seseorang lebih mendekati atau menjauhi orang lain. Seseorang akan melakukan atau tidak melakukan suatu perilaku sebelumnya telah mempertimbangkan apakah sikapnya positif atau negatif. ${ }^{10}$

Ada hubungan antara norma subjektif dengan minat untuk dirawat kembali, artinya sejauh mana pasien memiliki motivasi atau kepercayaan untuk mengikuti pandangan orang lain terhadap perilaku yang akan dilakukannya meliputi orang-orang terpandang, keluarga, tetangga, dokter, dan teman.

Hasil penelitian ini sesuai dengan penelitian yang dilakukan di RS Adi Husada Undaan Wetan yang menyatakan bahwa faktor norma subjektif berhubungan secara positif terhadap minat menggunakan layanan medical check up. Hal ini berarti responden memiliki keyakinan yang yang positif akan harapan kelompok acuannya untuk menggunakan layanan medical check up. ${ }^{9}$ Penelitian sebelumnya juga dilakukan di Klinik Mata Mojoagung Jombang tentang aplikasi Theory of Planned Behavior dalam membangkitkan niat pasien untuk melakukan oprasi katarak, hasil tersebut menunjukkan bahwa norma subjektif memiliki hubungan yang signifikan dengan niat untuk melakukan oprasi katarak. ${ }^{11}$ Penelitian ini, ketika norma subjektif ada disekitar individu mendukung dan menerima untuk memanfaatkan pelayanan kembali di rumah sakit maka akan semakin tinggi pula minat untuk dirawat kembali.

Tidak ada hubungan antara persepsi kontrol perilaku dengan minat untuk dirawat kembali. Artinya semakin individu merasakan banyak faktor pendukung dan sedikit faktor penghambat untuk dapat melakukan suatu perilaku, maka lebih besar kontrol perilaku yang mereka rasakan dan sebaliknya, jika semakin sedikit individu merasakan faktor pendukung dan banyak faktor penghambat, maka individu cenderung mempersepsikan diri sulit untuk melakukan perilaku tersebut. $^{12}$

Hasil penelitian ini sesuai dengan penelitian yang dilakukan di Universitas Muhammadiyah Yogyakarta, hasil pengujian persepsi kontrol perilaku menunjukkan tidak adanya berpengaruh positif terhadap niat whistleblowing internal dan whistleblowing eksterna. Namun, untuk pengujian moderasi variabel persepsi dukungan organisasi dengan 
variabel persepsi kontrol perilaku terhadap niat whistleblowing internal dan eksternal menghasilkan bahwa persepsi dukungan organisasi merupakan variabel pemoderasi yang memperkuat pengaruh persepsi kontrol perilaku terhadap niat whistlebowing internal dan eksternal. ${ }^{12}$ Penelitian lain yang dilakukan di Surabaya hasil ini menunjukkan bahwa pengaruh persepsi kontrol perilaku terhadap niat melakukan penggelapan pajak tidak signifikan, artinya bahwa tingkat persepsi seseorang terhadap kontrol yang dimilikinya dalam berperilaku tidak mendominasi atau mempengaruhi niat seseorang untuk berperilaku. ${ }^{13}$

Persepsi kontrol perilaku sebagai fungsi yang didasarkan oleh keyakinan yang disebut sebagai keyakinan kontrol, yaitu keyakinan individu mengenai ada atau tidak adanya faktor yang mendukung atau menghambat individu untuk melakukan suatu perilaku. Keyakinan ini didasarkan pada pengalaman masa lalu serta informasi dari pengalaman orang lain. $^{12}$

Tidak ada hubungan antara persepsi terhadap tempat (akses) dengan minat untuk dirawat kembali. Hasil ini sejalan dengan penelitian yang diterapkan di Kecamatan Pracimantoro Kab. Wonogiri yang menunjukkan bahwa tidak ada hubungan antara variabel persepsi tentang lokasi dengan minat dalam kepesertaan BPJS Kesehatan Mandiri. ${ }^{14}$

Perkembangan masyarakat kota Madiun saat ini begitu baik, dimana akses menuju rumah sakit mudah di tempuh baik itu dengan menggunakan angkutan umum maupun kendaraan pribadi. Waktu tempuh ke rumah sakit menjadi relatif singkat dengan adanya kemudahan sarana tranportasi seperti angkutan umum maupun kendaraan pribadi dan prasarana jalan yang baik sehingga masyarakat yang jauh dengan rumah sakit dapat mengakses tempat layanan tersebut. Kesulitan akses layanan kesehatan dapat teratasi dengan tersedianya sarana dan prasarana penunjang transportasi dari wilayah penduduk yang berada jauh dari lokasi pelayanan rumah sakit, untuk itu pembangunan jalan dan ketersediaan angkutan umum dapat menjadi cara untuk memudahkan masyarakat mendapatkan pelayanan kesehatan di rumah sakit, sehingga hubungan lokasi dengan pemanfaatan ulang, tempat dan kemudahan akses lokasi menuju sebuah rumah sakit dan unit pelayanan di dalamnya menjadi sangat penting bagi pasien.

Hasil analisis multivariat dapat
diketahui bahwa variabel yang berhubungan bermakna dengan minat untuk dirawat kembali adalah variabel kepuasan pasien. Hasil nilai OR dari kepuasan pasien terhadap minat untuk dirawat kembali setelah dikontrol variabel perancu (sikap) didapatkan sebesar 3,84 (IK 95\% : 0,98-15,12), artinya pasien yang puas terhadap pelayanan dokter dan perawat mempunyai peluang 3,84 kali berminat untuk dirawat kembali dibandingkan pasien yang tidak puas. Untuk hasil nilai $\mathrm{R}$ Square sebesar 0,579 $(57,9 \%)$ dengan demikian dapat di tafsirkan bahwa variabel minat untuk dirawat kembali dapat dijelaskan melalui kepuasan pasien, setelah dikontrol oleh variabel sikap terhadap pelayanan dokter dan perawat.

Hasil penelitian ini mendukung penelitian terdahulu yang dilakukan di RS Swasta Kota Banjarmasin yang menyatakan bahwa kepuasan pasien berpengaruh signifikan positif terhadap loyalitas pasien rawat inap. ${ }^{15}$ Dalam hal ini bahwa kepuasan pasien terjadi apabila apa yang menjadi kebutuhan, keinginan, dan harapan dapat dipenuhi, maka pasien akan puas, Sebuah pelayanan yang mampu membuat pasien untuk berkunjung kembali memanfaatkan jasanya, maka dapat dikatakan pasien tersebut puas atas pelayanan yang diberikan. ${ }^{7,16}$

Hal ini juga sesuai dengan penelitian di Ranotana Weru Kota Manado yang menyatakan ada hubungan antara kepuasan pasien terhadap kualitas jasa pelayanan rawat jalan dengan minat untuk 
memanfaatkan kembali pelayanan kesehatan. $^{7}$

Rumah sakit memegang peranan penting dalam pelayanan publik dan telah menjadi keharusannya untuk memberikan pelayanan yang berkualitas. Suatu kualitas pelayanan disebut baik apabila penyedia jasa memberikan pelayanan yang melebihi harapan pelanggan, sedangkan kualitas pelayanan disebut jelek apabila penyedia jasa memberikan pelayanan yang diberikan lebih rendah dari yang diharapkan pelanggan. Dalam era persaingan secara kompetitif ini rumah sakit harus berusaha mewujudkan kepuasan pasien, sebab jika kepuasan pasien tidak tercapai maka pasien pengguna pelayanan kesehatan akan berpindah dan menggunakan pelayanan yang diberikan rumah sakit lain yang lebih unggul dan lebih baik, hal ini akan menyebabkan penurunan kepercayaan dan pemanfaatan rumah sakit daerah sebagai institusi milik pemerintah. ${ }^{17}$

\section{KESIMPULAN}

Analisis kepuasan pasien terhadap pelayanan dokter dan perawat berhubungan dengan minat untuk dirawat kembali yang dilaksanakan di RSUD Dolopo Kabupaten Madiun diketahui memiliki hubungan yang dilihat dari indikator kepuasan pasien, sikap, dan norma subjektif dengan minat untuk dirawat kembali. Sedangkan persepsi kontrol perilaku, dan tempat (akses) tidak memiliki hubungan dengan minat untuk dirawat kembali. Setelah dikontrol sikap terhadap pelayanan dokter dan perawat, pasien yang merasa puas mempunyai 3,84 kali minat untuk dirawat kembali dibandingkan dengan yang tidak puas (OR $3,84 ; 95 \% \mathrm{CI}: 0,98-15,12 ; \mathrm{p}=0,054)$.

\section{DAFTAR PUSTAKA}

1. Herlambang S. Manajemen Pelayanan Kesehatan Rumah Sakit. Yogyakarta: Gosyen Publishing; 2016.

2. Undang-Undang Republik Indonesia Nomor 44 Tahun 2009 Tentang Rumah Sakit. Jakarta: 2009.
3. RSUD Dolopo Kabupaten Madiun. Profil Rumah Sakit Umum Daerah Dolopo Kabupaten Madiun. Madiun: 2012.

4. Rekam Medis RSUD Dolopo Kabupaten Madiun. Data Rekam Medis RSUD Dolopo Kabupaten Madiun. Madiun: 2015.

5. Satrianegara, M. Fais. Organisasi dan Manajemen Pelayanan Kesehatan Teori Dan Aplikasi Dalam Pelayanan Puskesmas Dan Rumah Sakit. Jakarta: Salemba Medika; 2014.

6. Prastiwi Niken E, dkk. Hubungan Kepuasan Pasien Bayar dengan Minat Kunjungan Ulang Di Puskesmas Wisma Jaya Kota Bekasi. Makara, Kesehatan Universitas Indonesia. Juni 2008; Vol. 12; No. 1.

7. Rondonuwu S. Natalya. at al. Hubungan Antara Kepuasan Pasien Terhadap Kualitas Jasa Pelayanan Rawat Jalan dengan Minat untuk Memanfaatkan Kembali Pelayanan Kesehatan Di Puskesmas Ranotana Weru Kota Manado. Fakultas Kesehatan Masyarakat Universitas Sam Ratulangi Manado; 2014.

8. Tjiptono, F. Total Quality Management. Yogyakarta: ANDI; 2000.

9. Chandoko, C. Perceived Behavioral Control merupakan Faktor Dominan yang Mempengaruhi Minat Menggunakan Layanan Medical Check Up. Jurnal Aplikasi Manajemen. Maret 2013; Vol. 11; No. 1.

10. Fitriani Yuni, at al. Path Analysis on the Determinants of the Use of Integrated Health Post and the Application of Theory of Planned Behavior. Journal of Health Promotion and Behavior School of Health Sciences STIKes Bhakti Mandala Husada Slawi and Faculty of Medicine Sebelas Maret University Surakarta. e-ISSN: 2549-1172. 2016.

11. Wikamorys Anggraini D, dkk. Aplikasi Theory Of Planned Behavioral Dalam Membangkitkan Niat Pasien untuk Melaksanakan Oprasi Katarak. Jurnal Administrasi 
Kesehatan Universitas Airlangga Surabaya. Januari-Juni 2017; Vol. 5; No. 1.

12. Saud, Maulani I. Pengaruh Sikap dan Persepsi Kontrol Perilaku Terhadap Niat Wheistleblowing InternalEksternal dengan Persepsi Dukungan Organisasi Sebagai Variabel Pemoderasi. Jurnal Akuntansi dan Investasi Universitas Muhammadiyah Yogyakarta. Juli 2016; Vol. 17; No. 2.

13. Wanarta Eileen F, dkk. Pengaruh Sikap Ketidak patuhan Pajak, Norma Subjektif, dan Kontrol Perilaku yang Dipersepsikan terhadap Niat Wajib Pajak Orang Pribadi untuk Melakukan Penggelapan Pajak. Tax and Accounting Review Akuntansi Pajak Universitas Kristen Petra. 2014; Vol. 4; No.1.

14. Mania Manja, et al. Analisis Hubungan Persepsi Bauran Pemasaran dengan Minat Petani Dalam Kepesertaan Bpjs Kesehatan Mandiri Di Kecamatan Pracimantoro Kabupaten Wonogiri. Jurnal Kesehatan Masyarakat Universitas Diponegoro Semarang. Juli 2017; Vol. 5; No. 3.

15. Djohan J, Agustinus. Faktor-Faktor yang Mempengaruhi Kepuasan dan Kepercayaan Untuk Mencapai Loyalitas Pasien Rawat Inap Pada Rumah Sakit Swasta Di Kota Banjarmasin. Jurnal Aplikasi Manajemen (JAM). Vol. 13; No. 2; 2015.

16. Nursalam. Manajemen Keperawatan Aplikasi Dalam Praktik Keperawatan Professional. Edisi 5. Jakarta: Salemba Medika; 2015.

17. Octavia A. et al. Analisis Kepuasan Pasien Rawat Inap Bangsal Jantung di RSUD Raden Mattaher jambi. Jurnal Manajemen Ekonomi Universitas Jambi. Januari-Maret 2012; Vol. 1; No. 1. 